\title{
Pharmacological Activities Of Phala-Varga (Medicinal Fruits) - An Ayurvedic Review
}

\author{
Umakant N. Rabb
}

\begin{abstract}
Ayurveda is not only a science of life but also a spiritual science. This branch of science deals with the proper life style and dietary advice by Ayurveda scholars. Among them vegetables and fruits are used to eradicate the diseases and helps to maintain the health of the person. Since Vedic period the fruits are used as Prasadam as well as in the form of Bhoga (Offering food), Upavasa (Fasting) purposes. The fruits are not only cure the diseases but also helps the mind in relaxed state. As per Ayurveda the fruits are classified on the basis of Rasa (Taste). For example sour fruit, sweet fruit, bitter fruit etc. The fruits are man source for fibers, multivitamins and minerals, which helps to repair the damaged cells. Here an attempt is made to bring the scattered information of various types of fruits from the classical sources and their pharmacological action on the body, are dealt elaborately. Further scope of the study is to cultivate such fruits in the classical manner and make available seasonally to the market in an affordable price.
\end{abstract}

Key Words - Ayurveda, Charaka Samhita, Sushruta Samhita, Phala-Varga, Bhavaprakasha Nighantu.

\section{INTRODUCTION}

In botany fruit is the seed bearing structure in flowering plants. Also called as angiosperms which is formed from the ovary after flowering. The fruits are the main source of nutrition. The outer edible layer is the Pericarp, formed from the ovary and surrounding the seeds. The pericarp possess three layers viz; Epicarp, Mesocarp, and Endocarp. The fruits have main source of Vitamin-C, Potassium, , Magnesium, calcium, Proteins etc. Since Vedic period the fruits are used as Prasadam in the form of Bhoga (Food), Upavasa (Fasting) purposes. The fruits are not only cure the diseases but also helps the mind in relaxed state. As per Ayurveda the fruits are classified on the basis of Rasa (Taste). For example sour fruit, sweet fruit, bitter fruit etc. Acharya Sushruta enumerated Dadima, Amalaka, Draksha, Kharjura, Parushaka, Matulunga, Rajadana are considered as best among the fruits. Whereas Acharya Charaka enumerated Mridvika (Dry grapes) are best and the Lakucha fruit is Ahita (Not healthy).

\section{DISCUSSION}

\section{A. AMRA PHALA ${ }^{[1],[2]}$ -}

Botanical Name- Mangifera indica Linn

Family- Anacardiaceae

Pharmacological Action- The Apakwa Amra Phala (Tender unripe) is Kashaya (Astringent), Vata-Pittakaraka, Matured mango fruit is Amla (Sour), Pitta Vardhaka, whereas Pakwa (Ripe) fruit is Vatashamaka, Vrishya (Aphrodisiac),
Balya (Tonic), Mamsavardhaka (Increases muscle bulk). The excess in take of sour mango causes Mandagni (Reduces digestive fire), Vishama Jwara (Intermittent fever), RaktaVikara (Blood disorders), Baddha Gudodara (Prolapse of the rectum during defaecation), Netra Roga (Eye diseases).

\section{B. MRIDVIKA PHALA ${ }^{[3],[4]}$.}

\section{Botanical Name- Vitis vinifera Linn}

Family- Vitaceae

Pharmacological Action- The Mridvika Phala is Madhura (Sweet) in taste, Vata-Pitta Shamaka, Sheeta Virya (Cold in potency), Snigdha (Demulcent), Brimhana (Nourishing), Vrishya (Aphrodisiac). Alleviates Jwara (fever), Kasahara (Cough), Raktapitta (Bleeding diseases), Kshata (Injury), Daurbalya (Generalized weakness).

\section{DADIMA PHALA ${ }^{[5],[6]-}$}

Botanical Name- Punica granatum Linn

Family- Punicaceae

Pharmacological Action- Dadima Phala is Tridoshagna (Subsides all the three Doshas), Deepana (Appetizer), Hridya (Cardio tonic), Grahi (Absorbent). As per Bhavaprakasha Nighantu he explained three types viz; Madhura (Sweet), Madhuramla (Sweet and Sour), Amla (Sour).

\section{KHARJURA PHALA ${ }^{[7]}$ -}

Botanical Name- Phoenix sylvestris Roxb Family- Arecaceae

Pharmacological Actions- Kharjura is Sheetala (Cold in potency), Madhura (Sweet) in taste, Vatapittahara (Subsides Vata Pitta Doshas), Brimhana (Nourishing), Vrushya (Aphrodisiac). The ripe fruit is used in Kshaya (Emaciation), Abhighata (Injury), Raktapitta (Haemorrhage), Daha (Burning sensation), Daurbalya (Weakness).

\section{E. KADALI PHALA $\left.{ }^{[8]}\right]_{-}$}

\section{Botanical Name- Musa paradisiaca Linn}

Family- Musaceae

Pharmacological Action- Pakwa Phala is Kashaya (Astringent), Madhura (Sweet), Guru (Heavy), Sheeta (Cold in potency), Vishtambhi (Causes constipation), Kaphavardhaka (Increases Kapha Dosha), Vatagna (Subsides Vata Doshas), Rakta Pitta Shamaka (Cures Bleeding diseases), Balya (Tonic), Vrishya (Aphrodisiac). 


\section{F. BADARA PHALA ${ }^{[9]}$ -}

Botanical Name- Ziziphus mauritiana Lam

Family- Rhamnaceae

Pharmacological Action- The unripe Badara fruit is Kapha-Pitta Vardhaka (Increases Kapha-Pitta Doshas), the ripe fruit is Madhura (Sweet) in taste, Vata-Pitta Shamaka (Subsides Vata and Pitta Doshas), Snigdha (Demulcent), Bhedana (Purgative). It is Hridya (Cardio tonic), Trishna Shamana (subsides thirst), Shramahara (Cures exhaustion). The Raja Badara is Balya (Tonic), Vrushya (Aphrodisiac). The gruel of Badara is Kapaha-Vatagna (Subsides Kapha and Vata Dosha), Trishnahara (Cures thirst), Sara (Laxative).

\section{G. PARUSHAKA PHALA ${ }^{[10],[11]}$ -}

Botanical Name- Grewia asiatica Linn

Family- Tiliaceae

Pharmacological Action- The fruit is Shramahara (Cures exhaustion), Jwarahara (Cures fever), It is mentioned Madhura Skandha in Charaka Samhita. As per Sushruta Samhita the fruit is Vatagna (Subsides Vata Dosha), Ruchikara (Appetizer), Trishnahara (Subsides thirst), Hridya (Cardio tonic), and Mutra Doshahara (Relieves urinary disorders).

\section{H. TOODA PHALA ${ }^{[12]}$}

Botanical Name- Morus alba Linn

Family- Moraceae

Pharmacological Actions- The fruit is Madhura (Sweet) in taste, Guru (Heavy), Sheeta (Cold) in potency, Vata-Pitta Shamaka (Subsides Vata-Pitta Doshas), In unripe it is Amla (Sour), Ushna Virya (Hot in potency), Raktapitta Prakopaka (Increases haemorrhage).

\section{GAMBHARI PHALA ${ }^{[13]}$ -}

Botanical Name- Gmelina arborea Linn

Family- Verbenaceae

Pharmacological Actions- The Gambhari fruit is Madhura-Kashaya (Sweet -Astringent) in taste, Madhura Vipaka (Sweet in post digestive effect), Sheeta Virya (Cold in potency), Snigdha (Demulcent), Vrushya (Aphrodisiac), Rasayana (Vitalizer). It is Raktasangrahika (Stops the bleeding), Raktapitta Shamaka (Haemorrhage).

\section{J. BILVA PHALA $A^{[14],[15]}$}

Botanical Name- Aegle marmelos Corr

Family- Rutaceae

Pharmacological Actions- The tender fruit of Bilva is Ushna (Hot in potency), Teekshna (Penetrating), Deepana (Appetizer), Sangrahi (Absorbent), Kapha-Vata Shamaka (Subsides Kapha and Vata Doshas) The ripe fruit is Guru (Heavy), Visthambhi (Causes constipation), Kostha Vata Vardhaka (Increases intestinal gas)

\section{K. PHALGU PHALA ${ }^{[16],[17]}$ -}

Botanical Name- Ficus carica Linn
Family- Moraceae

Pharmacological Action- The Phalgu Phala is Madhura (Sweet) in taste, Sheeta (Cold in potency), Guru (Heavy), Visthambhi (Causes constipation), Tarpana (Nourishing), Brimhana (Nutritious), Vata-Pitta Shamaka (Subsides Vata and Pitta Doshas), and Rakta-Pittahara (Cures bleeding diseases).

\section{BHALLATAKA PHALA ${ }^{[18]}$ -}

Botanical Name- Semicarpus anacardium Linn

Family- Anacardiaceae

Pharmacological Actions- The Bhallataka Phala is Madhura (Sweet) in taste, Sheetala (Cold in potency), Pitta Shamaka (Subsides Pitta Doshas), Keshya (Hair tonic).

\section{SHLESHMATAKA PHALA ${ }^{[19],[20]}$ -}

Botanical Name- Cordia dichotomz Forst.f.

Family- Boraginaceae

Pharmacological Actions- The ripe Shleshmataka Phala is Madhura (Sweet) in taste, Shleshmala (Increases Kapha Dosha), Guru (Heavy), Sheeta (Cold in potency). The unripe fruit is Ruksha (Dry), Visthambhi (Causes constipation), and Kapha-Pitta Shamaka (Subsides Kapha and Pitta)

\section{N. NARIKELA PHALA ${ }^{[21],[22]-}$}

Botanical Name- Cocos nucifera Linn

Family- Arecaceae

Pharmacological Actions- The Narikela Phala is Madhura (Sweet) in taste, Snigdha (Demulcent), Sheeta (Cold) in potency, Balya (Tonic), Brimhana (Nourishing), Vata-Pitta Shamaka (Subsides Vata and Pitta Doshas), Mutrala (Diuretic). The Narikela Jala is Sheetala (Cold) in potency, Hridya (Cardio tonic), Trishna Shamaka (Relieves thirst), Pitta Shamaka (Subsides Pitta Dosha), Mutrala (Diuretic). The tender coconut water is Pitta Shamaka (Subsides Pitta Dosha). Old coconut water is Pittakaraka (Increases Pitta), Vidahi (Causes burning sensation).

\section{O. TAALA PHALA ${ }^{[23],[24]}$ -}

Botanical Name- Borassus flabellifer Linn

Family- Palmae

Pharmacological Actions- The ripe Taala fruit is Madhura (Sweet) in taste, Snigdha (Deulcent), Sheeta (Cold) in potency Balya (Tonic), Brimhana (Nourishing), Guru (Heavy), Pitta Shamaka (Subsides Pitta Dosha).

\section{P. PANASA PHALA ${ }^{[25]}$}

Botanical Name- Artocarpus integra (Thunb) Merrill Family- Moraceae

Pharmacological Actions- The ripe Panasa fruit is Madhura-Kashaya (Sweet-Astringent) in taste, Snigdha (Demulcent), Sheeta (Cold) in potency, Guru (Heavy), VataPitta Shamaka (Subsides Vata-Pitta Doshas), Kapha Vardhaka (Increases Kapha), Balya (Tonic), Brimhana (Nourishing), The unripe fruit is Kashaya (Astringent), Guru (Heavy), VataVardhaka (Increases Vata Dosha), Vishtambhi (Causes constipation). 


\section{Q. LAKOOCHA PHALA ${ }^{[26]}$ -}

Botanical Name- Artocarpus lakoocha Roxb

Family- Moraceae

Pharmacological Actions- The unripe fruit of Lakoocha is Kashaya-Amla (Astringent-Sour), Guru (Heavy), Ushna (Hot in potency), Visthambhi (Causes constipation), Tridoshakopaka (Increases all the three Doshas; Vata-PittaKapha), Raktakopaka (Increases blood related diseases), Shukra Nashana (Depletes the semen), Agnimandyakara (Decreases appetite), Dristhinashaka (Depletes the vision). The ripe fruit is Madhura-Amla (Sweet-Sour) in taste, Vishtambhi (Causes constipation), Doshaprakopaka (Increases all the three Doshas; Vata-Pitta-Kapha).

\section{R. AROOKA PHALA ${ }^{[27]}$}

Botanical Name- Prunus persical Batsch

Family- Rosaceae

Pharmacological Actions- The Arooka Phala is Madhura (Sweet) in taste, Ruchikara (Tasty), Guru (Heavy), Ishad Ushna (Slightly hot in potency), Brimhana (Nourishing). Used in Prameha (Urinary diseases including diabetes), Arsha (Haemorrhoids), Gulma (Visceral organ diseases).

\section{S. URUMAANA PHALA ${ }^{[28]}$}

Botanical Name- Prunus armeniaca Linn

Family- Rosaceae

Pharmacological Actions- The Urumaana Phala (Apricot) is Madhura (Sweet) in taste, Snigdha (Demulcent), Guru (Heavy), Ushna (Hot) in potency, Balya (Tonic), Brimhana (Nourishing), Vatashamaka (Subsides Vata), Kapha-Pitta Vardhaka (Increases Kapha-Pitta Doshas).

\section{T. SEVA PHALA ${ }^{[29]}$}

Botanical Name- Pyrus malus Linn

Family- Rosaceae

Pharmacological Actions- The apple fruit is MadhuraKashaya (Sweet-Astringent) in taste, Sheeta Virya (Cold in potency), Vata-Pitta Shamaka (Subsides Vata and Pitta Doshas), Kapha Vardhaka (Increases Kapha Dosha), Brimhana (Nourishing), Grahi (Absorbent).

\section{U. TANKAM PHALA ${ }^{[30],[31]}$ -}

Botanical Name- Pyrus communis Linn

Family- Rosaceae

Pharmacological Actions- The Pear fruit is Madhura (Sweet), Kashaya (Astringent) in taste, Sheetala (Cold in potency), Balya (Tonic), Vatala (Increases Vata Dosha), Guru (Heavy).

\section{VATAADA PHALA ${ }^{[32]}$}

Botanical Name- Prunus amygdalus Batsch Family- Rosaceae

Pharmacological Actions- The Almond fruit is Madhura (Sweet), Guru (Heavy), Snigdha (Demulcent), Ushna (Hot) in potency, Kapha-Pitta Vardhaka (Increases Kapha and Pitta), Vata Shamaka (Subsides Vata Dosha), Balya (Tonic),

Vrushya (Aphrodisiac), Brimhana (Nourishing).

W. NIKOCHAKA PHALA ${ }^{[33]}$

Botanical Name- Pinus gerardiana Wall

Family- Pinaceae

Pharmacological Actions- The Nikochaka Phala is Guru (Heavy), Snigdha (Demulcent), Vrushya (Aphrodisiac), Swadu (Sweet) in taste, Dhatuvardhana (Increases all the seven Dhatus), Vatagna (Subsides Vata), Kapha-Pitta Krit (Increases Kapha and Pitta), Balya (Tonic), Brimhana (Nourishing), Ushna (Hot in potency).

\section{AKSHOTA PHALA ${ }^{[34]}$}

Botanical Name- Juglans regia Linn

Family- Juglandaceae

Pharmacological Actions- The Walnut fruit is Madhura (Sweet) in taste, Ushna (Hot in potency), Balya (Tonic), Vrushya (Aphrodisiac), Brimhana (Nourishing), Vatashamaka (Subsides Vata Dosha), Kapha-Pittakara (Increases Kapha and Pitta), Medha Vardhaka (Promotes intellect).

\section{Y. PRIYALA PHALA ${ }^{[35]}$ -}

Botanical Name- Buchanania lanzan Spreng

Family- Anacardiaceae

Pharmacological Actions- The Priyala Phala is Madhura (Sweet in taste), Snigdha (Demulcent), Sara (Laxative), Sheeta (Cold in potency), Balya (Tonic), Vrushya (Aphrodisiac), Brimhana (Nourishing), Vata-Pitta Shamaka (Subsides Vata and Pitta Doshas).

\section{Z. SHRINGATAKA PHALA ${ }^{[36]}$}

Botanical Name- Trapa natans Linn

Family- Trapaceae

Pharmacological Actions- The Shringataka Phala is Madhura (Sweet), Kashaya (Astringent) in taste, Guru (Heavy), Sheeta Virya (Cold in potency), Pitta Shamaka (Subsides Pitta Dosha), Kapha-Vata Vardhaka (Increases Kapha-Vata Dosha), Grahi (Absorbent), Vrushya (Aphrodisiac).

\section{AA. MAKHANA PHALA [37]_}

Botanical Name- Euryale ferox Salsib

Family- Nymphacaceae

Pharmacological Action- The fruit of Makhana is Madhura (Sweet), Sheeta (Cold in potency), Vata-Pitta Shamaka (Subsides Vata-Pitta Doshas), Balya (Tonic), Vrushya (Aphrodisiac), and it is Garbha Sthapana (Anti abortive).

\section{BB. PADMABEEJA ${ }^{[38]}$}

Botanical Name- Nelumbo nucifera Gaertn

Family- Nymphaceae

Pharmacological Actions- The fruit is Madhura-Kashaya (Sweet-Astringent in taste), Balya (Tonic), Vrushya (Aphrodisiac), Grahi (Absorbent), Pittashamaka (Subsides Pitta Dosha), Kapha-Vata Vardhaka (Increases Kapha and 
Vata Doshas), Garbhasthapana (Anti abortive).

\section{KUMUDA PHALA ${ }^{[39]}$ -}

Botanical Name- Nymphaea nouchali Burm. F.

Family- Nymphaceae

Pharmacological Actions- The fruit is used in Jwara (Fever) and Grahani (Dysentery).

\section{DD. TRAPUSA PHALA ${ }^{[40]}$}

Botanical Name- Cucumis sativus Linn

Family- Cucurbitaceae

Pharmacological Actions- The Trapusa fruit is Madhura (Sweet) in taste, Guru (Heavy), Ruksha (Dry), Sheeta (Cold in potency), Visthambhi (Causes constipation), Mutrala (Diuretic), Pittashamaka (Subsides Pitta Dosha), Raktapittahara (Cures haemorrhage).

\section{EE. ERVARUKA PHALA ${ }^{[41]}$}

Botanical Name- Cucumis utilissimus Linn

Family- Cucurbitaceae

Pharmcological Action- The Ervaruka fruit is KaphaVatakrit (Increases Kapha and Vata Doshas), Guru (Heavy), Swadu (Sweet in taste), Visthambhi (Causes constipation), Sheetala (Cold in potency).

\section{FF. KHARBUJA PHALA ${ }^{[42]}$}

Botanical Name- Cucumis melo Linn

Family- Cucurbitaceae

Pharmacological Actions- The fruit of Kharbuja is Guru (Heavy), Madhura (Sweet in taste), Sheeta (Cold in potency), Vata-Pitta Shamaka (Subsides Vata-Pitta Doshas), Mutrala (Diuretic), Balya (Tonic), Vrushya (Aphrodisiac), Sara (Laxative).

\section{GG. KAALINDA PHALA ${ }^{[43]}$}

Botanical Name- Citrullus vulgaris Schrad

Family- Cucurbitaceae

Pharmacological Actions- The water melon is Guru (Heavy), Sheetala (Cold in potency), Pittashamaka (Subsides Pitta), Grahi (Absorbent), Achakshushya (Not good for eyes), Avrushya (Non-aphrodisiac).

\section{HH. BAHUNETRA PHALA ${ }^{[44]}$ -}

Botanical Name- Ananas comosus (Linn) Merr

Family- Bromeliaceae

Pharmacological Actions- The pineapple is Madhura (Sweet), Amla (Sour) in taste, Vatashamaka (Subsides Vata Dosha), Kaphavardhaka (Increases Kapha Doshas), Sara (Laxative), Krimigna (Vermifuge), Balya (Tonic).

\section{MADHUKA PHALA ${ }^{[45]}$ -}

Botanical Name- Madhuka indica J. F. Gmel

Family- Sapotaceae

Pharmacological Actions- The Madhuka Phala is Madhura (Sweet) in taste, Sheeta (Cold in potency), Guru (Heavy), Vata-Pitta Shamaka (Subsides Vata-Pitta Doshas),
Vrushya (Aphrodisiac), Brimhana (Nourishing).

\section{JJ. NARANGA PHALA ${ }^{[46]}$}

Botanical Name- Citrus reticulata Blanco

Family- Rutaceae

Pharmacological Actions- The Naranga Phala is Madhuramla (Sweet-Sour) in taste, Hridya (Good for heart), Rochana (Appetizer), Vata Shamaka (Subsides Vata Dosha).

\section{KK. MISTHA NIMBAKA PHALA [47]}

Botanical Name- Citrus limettoides Tanaka

Family- Rutaceae

Pharmacological Actions- The sweet lime fruit is Madhura (Sweet in taste), Guru (Heavy), Vata-Pitta Shamaka (Subsides Vata and Pitta Doshas), Balya (Tonic), Rochana (Appetizer), Galaroga (Cures throat diseases), Visha (Poisonous effect), Raktapitta (Haemorrhage), Shosha (Emaciation), Trishna (Cures thirst), Kaphagna (Subsides Kapha Dosha).

\section{LL. BEEJAPURA PHALA ${ }^{[48]}$ -}

Botanical Name- Citrus medica Linn

Family- Rutaceae

Pharmacological Actions- The fruit of Beejapura is Deepana (Appetizer), Pachana (Digestive), Rochana (Taste promoter), Sara (Laxative), Hridya (Cardio tonic). It cures Shoola (Spasmodic pain), Gulma (Visceral organ diseases),Chardi (Vomiting), Ajirna (Indigestion), Arsha (Haemorrhoids).

\section{JAMBEERA PHALA ${ }^{[49]}$ -}

Botanical Name- Citrus limon (Linn), Burm.f.

Family- Rutaceae

Pharmacological Actions- The Jambeera fruit is Amla (Sour) in taste, Guru (Heavy), Ushna Virya (Hot in potency), Vata-Kapha Shamaka (Subsides Vata and Kapha Doshas), Sara (Laxative), Deepana (Appetizer), Pachana (Digestive). It cures Agnimandya (Loss of appetite), Shoola (Pain abdomen), Krimi (Worms), Chardi (Vomiting).

\section{NN. NIMBUKA PHALA ${ }^{[50]}$ -}

Botanical Name- Citrus aurantifolia (Christm) Swingle Family- Rutaceae

Pharmacological Action- The Nimbuka fruit is Rochana (Taste promoter), Deepana (Appetizer), Pachana (Digestive), Vatanulomana (Helps to easy evacuation of Vata Dosha).

\section{OO. AMALAKA PHALA [51],[52]}

Botanical Name- Emblica officinalis Gaertn

Family- Euphorbiaceae

Pharmacological Actions- The Amalaki fruit is Pancha Rasa Lavana Varjita Amla Pradhana (Possess five types of tastes except Salt), Madhura Vipaka (Sweet at the end of digestion), Sheeta Veerya (Cold in potency), Tridosha Shamaka (Subsides all the three Doshas especially Pitta Dosha), It cures Prameha (Urinary diseases including 
diabetes), Amlapiita (Hyper acidity), Raktapitta (Haemorrhage), Daurbalya (Generalized weakness).

\section{PP. BHAVYA PHALA [53]_}

Botanical Name- Dillenia indica Linn

Family- Dilleniaceae

Pharmacological Action- The Bhavya fruit is Swadu (Tasty), Kashaya (Astringent), Amla (Sour), Ruchikara (Taste promoter), Grahi (Absorbent), Guru (Heavy), Visthambhi (Causes constipation), Sheeta Virya (Cold in potency), KaphaPitta Vardhaka (Increases Kapha and Pitta Doshas).

\section{QQ. AMLIKA PHALA ${ }^{[54]}$ -}

Botanical Name- Tamarindus indica Linn

Family- Caesalpiniodeae

Pharmacological Actions- The Amlika Phala is Amla (Sour), Guru (Heavy), Ushna Virya (Hot in potency), Vata Shamaka (Subsides Vata Dosha), Kapha-Pitta Vardhaka (Increases Kapha and Pitta Doshas). The ripe fruit is Deepana (Appetizer), Sara (Laxative), Kapha-Vata Shamaka (Subsides Kapha and Vata Dosha).

\section{RR. KARMARANGA PHALA [55]}

Botanical Name- Averrhoa carambola Linn

Family- Oxalidaceae

Pharmacological Actions- The Karmaranga fruit is Sheetala (Cold in potency), Madhura (Sweet), Amla (Sour) in taste, Grahi (Absorbent), Kapha-Vata Shamaka (Subsides Kapha and Vata Doshas).

\section{SS. AMRATAKA PHALA ${ }^{[56]}$ -}

Botanical Name- Spondias pinnata Linn

Family- Anacardiaceae

Pharmacological Actions- The unripe Amrataka Phala is Amla (Sour), Ushna (Hot in potency), Sara (Laxative), Rochana (Taste promoter). The ripe Amrataka fruit is Madhura (Sweet), Amla (Sour), Sheeta (Cold in potency), Vata-Pitta Shamaka (Subsides Vata and Pitta Doshas), Balya (Tonic).

\section{TT. KARAMARDA PHALA [57] -}

Botanical Name- Carissa carandus Linn

Family- Apocynaceae

Pharmacological Actions- The unripe fruit of Karamarda is Amla (Sour), Ushna (Hot in potency), Ruchikara (Tasty), Trishna Shamaka (Cures thirst), Kapha-Pitta Vardhaka (Increases Kapha and Pitta Doshas). The ripe fruit is Madhura (Sweet), Vata-Pitta Shamaka (Subsides Vata and Pitta Doshas).

\section{UU. KAPITTHA PHALA ${ }^{[58]}$}

Botanical Name- Feronia limonia (Linn) Swingle Family- Rutaceae

Pharmacological Actions- The unripe fruit is Kashaya (Astringent), Sangrahi (Absorbent), Swarabhedaka (Causes hoarseness of voice), Vata Vardhaka (Increases Vata
Dosha). The ripe fruit is Madhura (Sweet), Amla (Sour), Vata-Pitta Shamaka (Subsides Vata and Pitta), Grahi (Absorbent), Trishna Shamaka (Cures thirst).

\section{VV. KOSHAMRA PHALA ${ }^{[59]}$ -}

Botanical Name- Schleichera oleosa (Lour) Oken Family- Sapindaceae

Pharmacological Actions- The Koshamra Phala is Amla (Sour), Guru (Heavy), Ushna (Hot in potency), Vata Shamaka (Subsides Vata), Kapha-Pitta Vardhaka (Increases Kapha and Pitta Doshas), Grahi (Absorbent), Trishna Shamaka (Cures thirst).

\section{WW. PRACHINAMALAKA PHALA ${ }^{[60]}$ -}

Botanical Name- Flacourtia jangomas Raeusch

Family- Flacourtiaceae

Pharmacological Actions- The Prachinamalaka fruit is Tridosha Shamaka (Subsides all the three Doshas; VataPitta-Kapha), Vishagna (Subsides Poisonous effects), Jwaragna (Cures fever).

\section{$X X$. JAMBU PHALA ${ }^{[61],[62]}$}

Botanical Name- Syzygium cumini (Linn), Skeels Family- Myrtaceae

Pharmacological Actions- The Jambu Phala is Kashaya (Astringent), Amla (Sour), Madhura (Sweet) in taste, Ruksha (Dry), Vata Vardhaka (Increses Vata Doshas), Kapha-Pitta Shamaka (Subsides Kapha-Pitta Doshas), Grahi (Absorbent), Pramehagna (Cures urinary diseases including diabetes), Medoroga (Obesity).

\section{YY. UDUMBARA PHALA ${ }^{[63]}$}

Botanical Name- Ficus glomerata

Family- Moraceae

Pharmacological Actions- The Udumbara fruit is Kashaya (Astringent), Sheeta Virya (Cold in potency), Stambhana, Rakta-Pitta Shamaka (Cures haemorrhage), Grahani (Dysentery), Prameha (Urinary diseases including diabetes).

\section{ZZ. TINDUKA PHALA ${ }^{[64]}$}

Botanical Name- Diospyros peregrina (Gaertn) Guerke Family- Ebenaceae

Pharmacological Actions- The Tinduka Phala is Kashaya (Astringent), Madhura (Sweet), Kapha-Pitta Shamaka (Subsides Kapha and Pitta Doshas), Cures Raktapitta (Haemorrhage), Prameha (Urinary diseases including diabetes).

\section{AAA. BAKULA PHALA [65], [66]_}

Botanical Name- Mimusops elengi Linn

Family- Sapotaceae

Pharmacological Actions- The Bakula Phala is Kashaya (Astringent), Madhura (Sweet), Sheeta (Cold in potency), Kapha-Pitta Shamaka (Subsides Kapha-Pitta Doshas), Vata Vardhaka (Increases Vata Dosha), Hridya (Cardio tonic), Grahi (Absorbent), Dantaroga (Used for teeth diseases). 


\section{BBB. KSHEERIKA PHALA ${ }^{[67]}$ -}

Botanical Name- Manilkara hexandra Roxb

Family- Sapotaceae

Pharmacological Actions- The Ksheerika Phala is Snigdha (Demulcent), Sheeta (Cold in potency), Guru (Heavy), Tridosha Shamaka (Subsides all the three Doshas; Vata-Pitta-Kapha), Balya (Tonic), Vrushya (Aphrodisiac), Brimhana (Nourishing).

\section{KADAMBA PHALA ${ }^{[68]}$}

Botanical Name- Anthocephalus indicus Miq

Family- Rubiaceae

Pharmacological Actions- The Kadamba Phala is Guru (Heavy), Kashaya (Astringent), Madhura (Sweet), Sheeta Virya (Cold in potency), Abhishyandi (Obstructs the channels), Vata-Pitta Shamaka (Subsides Vata-Pitta Doshas).

\section{DDD. KAREERA PHALA ${ }^{[69]}$}

Botanical Name- Capparis decidua Edgew

Family- Capparidaceae

Pharmacological Actions- The Kareera Phala is Madhura (Sweet), Katu (Pungent), Tikta (Bitter) in taste, Ushna Virya (Hot in potency), Kapha-Vata Shamaka (Subsides Kapha-Vata Doshas).

\section{EEE. SHAMI PHALA ${ }^{[70]}$}

Botanical Name- Prosopis cineraria Druce

Family- Fabaceae

Pharmacological Actions- The Shami Phala is Madhura (Sweet) in taste, Ruksha (Dry), Ushna (Hot in potency), Keshagna (Causes hair loss).

\section{FFF. PEELU PHALA [71],[72]_}

Botanical Name- Salvadora persica Linn

Family- Salvadoraceae

Pharmacological Action- The Peelu Phala is Tikta (Bitter), Katu (Pungent), Teekshna (Penetrating), Ushna (Hot in potency), Snigdha (Demulcent), Sara (Laxative), Bhedana (Purgative), Cures Visha (Poison effect), Kapha-Vata Shamaka (Subsides Kapha-Vata Doshas), Pitta Vardhaka (Increases Vata Dosha). The unripe fruit is Madhura (Sweet), Tikta (Bitter), Ishat Ushna (Not much hot in potency), Tridosha Shamaka (Subsides all the three Doshas; VataPitta-Kapha), Gulma (Cures Visceral organ diseases).

\section{GGG. POOGA PHALA ${ }^{[73],[74]}$ -}

Botanical Name-Areca catechu Linn

Family- Arecaceae

Pharmacological Actions- The fruit of betel nut is Guru (Heavy), Hima (Cold in potency), Kashaya (Astringent), Kapha-Pittajit (Subsides Kapha and Pitta Doshas), Mohanakara (Produces drowsiness), Deepana (Appetizer), Ruchya (Tasty), Asya Vairasya Nashana (Subsides lethargy). The wet fruit of betel nut is Guru (Heavy), Abhishyandi (Obstructs the channels), Agnimandyakara (Produces Loss of appetite), Drishtihara (Produces Loss of vision), The boiled fruit of betel nut cures Chardi (Vomitimg), Tridoshahara (Subsides all the three Doshas; Vata-Pitta-Kapha).

\section{HHH. KATAKA PHALA ${ }^{[75]}$}

Botanical Name- Strychnos potatorum Linn

Family- Loganiaceae

Pharmacological Action- The Kataka fruit is VataShleshmahara (Subsides Vata and Kapha Doshas), Sheeta (Cold in potency), Madhura (Sweet), Kashaya (Astringent) in taste, Guru (Heavy), Netrya (Good for eyes).

\section{AMLAVETASA PHALA ${ }^{[76]}$ -}

Botanical Name- Garcinia pedunculata Roxb

Family- Clusiaceae

Pharmacological Actions- The Garcinia fruit is Amla (Sour) in taste, Bhedana (Purgative), Laghu (Light), Deepana (Appetizer), Cures Hridroga (Heart related diseases), Shoola (Pain abdomen), Hikka (Hiccough), Anaha (Distentin of the abdomen), Shwasa (Dyspnoea), Kasa (Cough), Ajirna (Indigestion), Udavarta (Sour belching), Pleehodara (Enlargement of spleen)

\section{JJJ. VRIKSHAMLA PHALA ${ }^{[77]}$}

Botanical Name- Garcinia indica Chois

Family- Clusiaceae

Pharmacological Action- The Vrikshamla fruit is Amla (Sour), Ushna (Hot in potency), Vatahara (Subsides Vata Dosha), Guru (Heavy), Rochana (Tasty), Ruksha (Dry), Deepana (Appetizer), Sangrahi (Absorbent). Cures Trishna (Thirst), Arsha (Haemorrhoids), Grahani (Dysentery), Gulma (Visceral organ diseases), Shoola (Pain abdomen), Hridroga (Heart diseases), Jantu (Worm infestation).

\section{CONCLUSION-}

All the mentioned fruits possess the anti-oxidant, aphrodisiac property, anti-poisonous activity, anti-obesity activity, cardio tonic activity. Some of them contain rich in fibers which help to easy evacuation of the faeces. These fruits not only helps to prevent the diseases but also helps to maintain the health of the person. The further scope of study is to carry such pharmacological activities and make available these original and classical method of cultivated fruits in the market in an affordable price, so that the manifestation of the disease will be reduced and helps to maintain the health of the person.

\section{REFERENCES}

[1] Acharya Charaka, Charaka Samhita Sutrasthana 27 th chapter, shloka No-139, Charaka Chandrika Hindi Commentary of Agnivesha, edited by Dr.Bramhanand Tripathi, Chaukhambha Surabharati Prakashana, Varanasi, Reprint 2002, Page no-517.

[2] Acharya Bhavamishra of Bhavaprakasha Nighantu,Amradi Phala Varga, Shloka No-11-14, by Dr. Bulusu Sitaram, Volume 1, Chaukhambha Orientalia, Varanasi, First edition 2006, Page No- 362

[3] Acharya Charaka, Charaka Samhita, Sutrasthana 27th chapter, Shloka No-127, Charaka Chandrika Hindi commentary of Agnivesha, edited by Dr. Bramhananda Tripathi, Chaukhamha Surabharati Prakashana, Varanasi, Reprint, 2002; Page No-515. 
[4] Acharya Bhavamishra of Bhavaprakasha Nighantu,Amradi Phala Varga, Shloka No-109-114, by Dr. Bulusu Sitaram, Volume 1, Chaukhambha Orientalia, Varanasi, First edition 2006, Page No- 386.

[5] Acharya Charaka, Charaka Samhita, Sutrasthana 27th chapter, Shloka No-150, Charaka Chandrika Hindi commentary of Agnivesha, edited by Dr. Bramhananda Tripathi, Chaukhamha Surabharati Prakashana, Varanasi, Reprint, 2002; Page No-51.

[6] Acharya Bhavamishra of Bhavaprakasha Nighantu,Amradi Phala Varga, Shloka No-101-104, by Dr. Bulusu Sitaram, Volume 1, Chaukhambha Orientalia, Varanasi, First edition 2006, Page No- 384.

[7] Acharya Bhavamishra of Bhavaprakasha Nighantu,Amradi Phala Varga, Shloka No-115-122, by Dr. Bulusu Sitaram, Volume 1, Chaukhambha Orientalia, Varanasi, First edition 2006, Page No- 387.

[8] Acharya Bhavamishra of Bhavaprakasha Nighantu,Amradi Phala Varga, Shloka No-33-35, by Dr. Bulusu Sitaram, Volume 1, Chaukhambha Orientalia, Varanasi, First edition 2006, Page No- 367.

[9] Acharya Bhavamishra of Bhavaprakasha Nighantu,Amradi Phala Varga, Shloka No-73-77, by Dr. Bulusu Sitaram, Volume 1, Chaukhambha Orientalia, Varanasi, First edition 2006, Page No- 376.

[10] Acahrya Sushruta, Sushruta Samhita, Purvardha, Sutrasthana 38th chapter, Shloka No-43, Ayurveda Tatva Sandipika, Hindi commentary, edited by Kaviraja Dr. Ambikadatta Shastry, Chaukhamba Sanskrit Samsthan, Varanasi, Reprint, Page No-186.

[11] Acharya Bhavamishra of Bhavaprakasha Nighantu,Amradi Phala Varga, Shloka No-98-99, by Dr. Bulusu Sitaram, Volume 1 , Chaukhambha Orientalia, Varanasi, First edition 2006, Page No- 383.

[12] Acharya Bhavamishra of Bhavaprakasha Nighantu,Amradi Phala Varga, Shloka No-100, by Dr. Bulusu Sitaram, Volume 1 , Chaukhambha Orientalia, Varanasi, First edition 2006, Page No- 383.

[13] Acharya Charaka, Charaka Samhita, Sutrasthana 27th chapter, Shloka No-135, Charaka Chandrika Hindi commentary of Agnivesha, edited by Dr. Bramhananda Tripathi, Chaukhamha Surabharati Prakashana, Varanasi, Reprint, 2002; Page No-516.

[14] Acahrya Sushruta, Sushruta Samhita, Purvardha, Sutrasthana 46th chapter, Shloka No-209, Ayurveda Tatva Sandipika, Hindi commentary, edited by Kaviraja Dr. Ambikadatta Shastry, Chaukhamba Sanskrit Samsthan, Varanasi, Reprint, Page No-260.

[15] Acharya Bhavamishra of Bhavaprakasha Nighantu,Amradi Phala Varga, Shloka No-56-60, by Dr. Bulusu Sitaram, Volume 1, Chaukhambha Orientalia, Varanasi, First edition 2006, Page No- 372.

[16] Acharya Charaka, Charaka Samhita, Sutrasthana 27th chapter, Shloka No-128, Charaka Chandrika Hindi commentary of Agnivesha, edited by Dr. Bramhananda Tripathi, Chaukhamha Surabharati Prakashana, Varanasi, Reprint, 2002; Page No-515.

[17] Acharya Bhavamishra of Bhavaprakasha Nighantu, Vatadi Varga, Shloka No-10, by Dr. Bulusu Sitaram, Volume 1, Chaukhambha Orientalia, Varanasi, First edition 2006, Page No- 339.

[18] Acharya Charaka, Charaka Samhita, Sutrasthana 27th chapter, Shloka No-165, Charaka Chandrika Hindi commentary of Agnivesha, edited by Dr. Bramhananda Tripathi, Chaukhamha Surabharati Prakashana, Varanasi, Reprint, 2002; Page No-519.

[19] Acharya Charaka, Charaka Samhita, Sutrasthana 27th chapter, Shloka No-159-160, Charaka Chandrika Hindi commentary of Agnivesha, edited by Dr. Bramhananda Tripathi, Chaukhamha Surabharati Prakashana, Varanasi, Reprint, 2002; Page No-519.

[20] Acharya Bhavamishra of Bhavaprakasha Nighantu, Amradi Phala Varga, Shloka No-106-107, by Dr. Bulusu Sitaram, Volume 1, Chaukhambha Orientalia, Varanasi, First edition 2006, Page No- 385.

[21] Acahrya Sushruta, Sushruta Samhita, Purvardha, Sutrasthana 46th chapter, Shloka No-180, Ayurveda Tatva Sandipika, Hindi commentary, edited by Kaviraja Dr. Ambikadatta Shastry, Chaukhamba Sanskrit Samsthan, Varanasi, Reprint, Page No-258

[22] Acharya Bhavamishra of Bhavaprakasha Nighantu,Amradi Phala Varga, Shloka No-39-42, by Dr. Bulusu Sitaram, Volume 1, Chaukhambha Orientalia, Varanasi, First edition 2006, Page No-368

[23] Acharya Charaka, Charaka Samhita, Sutrasthana 27th chapter, Shloka No-130, Charaka Chandrika Hindi commentary of Agnivesha, edited by Dr. Bramhananda Tripathi, Chaukhamha Surabharati Prakashana, Varanasi, Reprint, 2002; Page No-515.

[24] Acahrya Sushruta, Sushruta Samhita, Purvardha, Sutrasthana 46th chapter, Shloka No-178, Ayurveda Tatva Sandipika, Hindi commentary, edited by Kaviraja Dr. Ambikadatta Shastry, Chaukhamba Sanskrit Samsthan, Varanasi, Reprint, Page No-258.

[25] Acharya Bhavamishra of Bhavaprakasha Nighantu,Amradi Phala Varga, Shloka No-25-27, by Dr. Bulusu Sitaram, Volume 1, Chaukhambha Orientalia, Varanasi, First edition 2006, Page No- 365366.

[26] Acharya Bhavamishra of Bhavaprakasha Nighantu,Amradi Phala Varga, Shloka No-30-32 by Dr. Bulusu Sitaram, Volume 1, Chaukhambha Orientalia, Varanasi, First edition 2006, Page No- 366
[27] Acharya Charaka, Charaka Samhita, Sutrasthana 27th chapter, Shlok No-133, Charaka Chandrika Hindi commentary of Agnivesha, edited by Dr. Bramhananda Tripathi, Chaukhamha Surabharati Prakashana, Varanasi, Reprint, 2002; Page No-516.

[28] Acahrya Sushruta, Sushruta Samhita, Purvardha, Sutrasthana 46th chapter, Shloka No-187, Ayurveda Tatva Sandipika, Hindi commentary, edited by Kaviraja Dr. Ambikadatta Shastry, Chaukhamba Sanskrit Samsthan, Varanasi, Reprint, Page No-259

[29] Acharya Bhavamishra of Bhavaprakasha Nighantu,Amradi Phala Varga, Shloka No-389, by Dr. Bulusu Sitaram, Volume 1 , Chaukhambha Orientalia, Varanasi, First edition 2006, Page No- 126.

[30] Acharya Charaka, Charaka Samhita, Sutrasthana 27th chapter, Shloka No-136-137, Charaka Chandrika Hindi commentary of Agnivesha, edited by Dr. Bramhananda Tripathi, Chaukhamha Surabharati Prakashana, Varanasi, Reprint, 2002; Page No-516.

[31] Acharya Bhavamishra of Bhavaprakasha Nighantu,Amradi Phala Varga, Shloka No-125-126, by Dr. Bulusu Sitaram, Volume 1, Chaukhambha Orientalia, Varanasi, First edition 2006, Page No- 389

[32] Acharya Bhavamishra of Bhavaprakasha Nighantu,Amradi Phala Varga, Shloka No-123-124, by Dr. Bulusu Sitaram, Volume 1, Chaukhambha Orientalia, Varanasi, First edition 2006, Page No- 388.

[33] Bhagwan Dash, Madana pal nighantu, Phala Varga, Shloka No- 67-68, B. Jain publishers pvt. Ltd, first edition, New Delhi 1991 Page no-290

[34] Bhavamishra of Bhavaprakasha Nighantu,Amradi Phala Varga, Shloka No-129, by Dr. Bulusu Sitaram, Volume 1, Chaukhambha Orientalia, Varanasi, First edition 2006, Page No- 390

[35] Acharya Bhavamishra of Bhavaprakasha Nighantu,Amradi Phala Varga, Shloka No-83-85, by Dr. Bulusu Sitaram, Volume 1, Chaukhambha Orientalia, Varanasi, First edition 2006, Page No- 379.

[36] Acharya Bhavamishra of Bhavaprakasha Nighantu,Amradi Phala Varga, Shloka No-92-93, by Dr. Bulusu Sitaram, Volume 1, Chaukhambha Orientalia, Varanasi, First edition 2006, Page No- 381.

[37] Acharya Bhavamishra of Bhavaprakasha Nighantu,Amradi Phala Varga, Shloka No-91, by Dr. Bulusu Sitaram, Volume 1, Chaukhambha Orientalia, Varanasi, First edition 2006, Page No- 381.

[38] Acharya Bhavamishra of Bhavaprakasha Nighantu,Amradi Phala Varga, Shloka No-89-90, by Dr. Bulusu Sitaram, Volume 1, Chaukhambha Orientalia, Varanasi, First edition 2006, Page No- 380.

[39] Acharya Bhavamishra of Bhavaprakasha Nighantu, Pushpa Varga, Shloka No-15-18, by Dr. Bulusu Sitaram, Volume 1, Chaukhambha Orientalia, Varanasi, First edition 2006, Page No- 318.

[40] Acharya Bhavamishra of Bhavaprakasha Nighantu, Amradi Phala Varga, Shloka No-47-48, by Dr. Bulusu Sitaram, Volume 1, Chaukhambha Orientalia, Varanasi, First edition 2006, Page No- 370.

[41] Acharya Charaka, Charaka Samhita, Sutrasthana 27th chapter, Shloka No-133, Charaka Chandrika Hindi commentary of Agnivesha, edite by Dr. Bramhananda Tripathi, Chaukhamha Surabharati Prakashana, Varanasi, Reprint, 2002; Page No-516.

[42] Acharya Bhavamishra of Bhavaprakasha Nighantu,Amradi Phal Varga, Shloka No-44-46, by Dr. Bulusu Sitaram, Volume 1 Chaukhambha Orientalia, Varanasi, First edition 2006, Page No- 367368

[43] Acharya Bhavamishra of Bhavaprakasha Nighantu,Amradi Phala Varga, Shloka No-43, by Dr. Bulusu Sitaram, Volume 1, Chaukhambha Orientalia, Varanasi, First edition 2006, Page No- 369.

[44] Raj Vall nigh by Raja Vallabh Acharya, edited by Shrimadbhishag shiromani Narayana Das, 1952, Laxmivenkateshwar mudranalaya, Kalyan, Mumbai

[45] Acharya Bhavamishra of Bhavaprakasha Nighantu,Amradi Phala Varga, Shloka No-95-97, by Dr. Bulusu Sitaram, Volume 1 Chaukhambha Orientalia, Varanasi, First edition 2006, Page No- 382.

[46] Acharya Charaka, Charaka Samhita, Sutrasthana 27th chapter, Shloka No-156, Charaka Chandrika Hindi commentary of Agnivesha, edited by Dr. Bramhananda Tripathi, Chaukhamha Surabharati Prakashana, Varanasi, Reprint, 2002; Page No-518.

[47] Acharya Bhavamishra of Bhavaprakasha Nighantu,Amradi Phala Varga, Shloka No-139-140, by Dr. Bulusu Sitaram, Volume 1, Chaukhambha Orientalia, Varanasi, First edition 2006, Page No- 393.

[48] Acharya Bhavamishra of Bhavaprakasha Nighantu,Amradi Phal Varga, Shloka No-130-131, by Dr. Bulusu Sitaram, Volume 1 , Chaukhambha Orientalia, Varanasi, First edition 2006, Page No- 391.

[49] Acharya Bhavamishra of Bhavaprakasha Nighantu,Amradi Phala Varga, Shloka No-134-135, by Dr. Bulusu Sitaram, Volume 1 , Chaukhambha Orientalia, Varanasi, First edition 2006, Page No- 392.

[50] Acharya Bhavamishra of Bhavaprakasha Nighantu,Amradi Phala Varga, Shloka No-136-138, by Dr. Bulusu Sitaram, Volume 1, Chaukhambha Orientalia, Varanasi, First edition 2006, Page No- 392.

[51] Acahrya Sushruta, Sushruta Samhita, Purvardha, Sutrasthana 46th chapter, Shloka No-143-144, Ayurveda Tatva Sandipika, Hindi 
commentary, edited by Kaviraja Dr. Ambikadatta Shastry, Chaukhamba Sanskrit Samsthan, Varanasi, Reprint, Page No-255-256

[52] Acharya Bhavamishra of Bhavaprakasha Nighantu, Haritakyadi Varga, Shloka No-39-41, by Dr. Bulusu Sitaram, Volume 1, Chaukhambha Orientalia, Varanasi, First edition 2006, Page No- 135.

[53] Acharya Charaka, Charaka Samhita, Sutrasthana 27th chapter, Shloka No-132, Charaka Chandrika Hindi commentary of Agnivesha, edited by Dr. Bramhananda Tripathi, Chaukhamha Surabharati Prakashana, Varanasi, Reprint, 2002; Page No-515.

[54] Acharya Bhavamishra of Bhavaprakasha Nighantu,Amradi Phala Varga, Shloka No-142-143, by Dr. Bulusu Sitaram, Volume 1, Chaukhambha Orientalia, Varanasi, First edition 2006, Page No- 394.

[55] Acharya Bhavamishra of Bhavaprakasha Nighantu,Amradi Phala Varga, Shloka No-141, by Dr. Bulusu Sitaram, Volume 1, Chaukhambha Orientalia, Varanasi, First edition 2006, Page No- 393.

[56] Acharya Bhavamishra of Bhavaprakasha Nighantu,Amradi Phala Varga, Shloka No-19-20, by Dr. Bulusu Sitaram, Volume 1, Chaukhambha Orientalia, Varanasi, First edition 2006, Page No- 364.

[57] Acharya Bhavamishra of Bhavaprakasha Nighantu,Amradi Phala Varga, Shloka No-81-83, by Dr. Bulusu Sitaram, Volume 1, Chaukhambha Orientalia, Varanasi, First edition 2006, Page No- 378.

[58] Acharya Charaka, Charaka Samhita, Sutrasthana 27th chapter, Shloka No-136-137, Charaka Chandrika Hindi commentary of Agnivesha, edited by Dr. Bramhananda Tripathi, Chaukhamha Surabharati Prakashana, Varanasi, Reprint, 2002; Page No-516.

[59] Acharya Bhavamishra of Bhavaprakasha Nighantu,Amradi Phala Varga, Shloka No-23-24, by Dr. Bulusu Sitaram, Volume 1, Chaukhambha Orientalia, Varanasi, First edition 2006, Page No- 365.

[60] Acharya Bhavamishra of Bhavaprakasha Nighantu,Amradi Phala Varga, Shloka No-23-24, by Dr. Bulusu Sitaram, Volume 1, Chaukhambha Orientalia, Varanasi, First edition 2006, Page No- 365.

[61] Acharya Charaka, Charaka Samhita, Sutrasthana 27th chapter, Shloka No-140, Charaka Chandrika Hindi commentary of Agnivesha, edited by Dr. Bramhananda Tripathi, Chaukhamha Surabharati Prakashana, Varanasi, Reprint, 2002; Page No-517.

[62] Acahrya Sushruta, Sushruta Samhita, Purvardha, Sutrasthana 46th chapter, Shloka No-166, Ayurveda Tatva Sandipika, Hindi commentary, edited by Kaviraja Dr. Ambikadatta Shastry, Chaukhamba Sanskrit Samsthan, Varanasi, Reprint, Page No-257

[63] Acharya Charaka, Charaka Samhita, Sutrasthana 27th chapter, Shloka No-164, Charaka Chandrika Hindi commentary of Agnivesha, edited by Dr. Bramhananda Tripathi, Chaukhamha Surabharati Prakashana, Varanasi, Reprint, 2002; Page No-518

[64] Acharya Bhavamishra of Bhavaprakasha Nighantu,Amradi Phala Varga, Shloka No-65, by Dr. Bulusu Sitaram, Volume 1, Chaukhambha Orientalia, Varanasi, First edition 2006, Page No- 374.

[65] Acahrya Sushruta, Sushruta Samhita, Purvardha, Sutrasthana 46th chapter, Shloka No-169, Ayurveda Tatva Sandipika, Hindi commentary, edited by Kaviraja Dr. Ambikadatta Shastry, Chaukhamba Sanskrit Samsthan, Varanasi, Reprint, Page No-257

[66] Acharya Bhavamishra of Bhavaprakasha Nighantu, Pushpa Varga, Shloka No-33-35, by Dr. Bulusu Sitaram, Volume 1, Chaukhambha Orientalia, Varanasi, First edition 2006, Page No- 323.

[67] Acharya Bhavamishra of Bhavaprakasha Nighantu,Amradi Phala Varga, Shloka No-86-87, by Dr. Bulusu Sitaram, Volume 1, Chaukhambha Orientalia, Varanasi, First edition 2006, Page No- 379.

[68] Acahrya Sushruta, Sushruta Samhita, Purvardha, Sutrasthana 46th chapter, Shloka No-158, Ayurveda Tatva Sandipika, Hindi commentary, edited by Kaviraja Dr. Ambikadatta Shastry, Chaukhamba Sanskrit Samsthan, Varanasi, Reprint, Page No-256

[69] Acahrya Sushruta, Sushruta Samhita, Purvardha, Sutrasthana 46th chapter, Shloka No-193, Ayurveda Tatva Sandipika, Hindi commentary, edited by Kaviraja Dr. Ambikadatta Shastry, Chaukhamba Sanskrit Samsthan, Varanasi, Reprint, Page No-259

[70] Sushruta, Sushruta Samhita, Purvardha, Sutrasthana 46th chapter, Shloka No-192, Ayurveda Tatva Sandipika, Hindi commentary, edited by Kaviraja Dr. Ambikadatta Shastry, Chaukhamba Sanskrit Samsthan, Varanasi, Reprint, Page No-259

[71] Acahrya Sushruta, Sushruta Samhita, Purvardha, Sutrasthana 46th chapter, Shloka No-194, Ayurveda Tatva Sandipika, Hindi commentary, edited by Kaviraja Dr. Ambikadatta Shastry, Chaukhamba Sanskrit Samsthan, Varanasi, Reprint, Page No-259

[72] Acharya Bhavamishra of Bhavaprakasha Nighantu,Amradi Phala Varga, Shloka No-128, by Dr. Bulusu Sitaram, Volume 1, Chaukhambha Orientalia, Varanasi, First edition 2006, Page No- 390.

[73] Acharya Bhavamishra of Bhavaprakasha Nighantu,Amradi Phala Varga, Shloka No-50-51, by Dr. Bulusu Sitaram, Volume 1, Chaukhambha Orientalia, Varanasi, First edition 2006, Page No- 371.
[74] Acahrya Sushruta, Sushruta Samhita, Purvardha, Sutrasthana 46th chapter, Shloka No-201-204, Ayurveda Tatva Sandipika, Hindi commentary, edited by Kaviraja Dr. Ambikadatta Shastry, Chaukhamba Sanskrit Samsthan, Varanasi, Reprint, Page No-260

[75] Acharya Bhavamishra of Bhavaprakasha Nighantu ,Amradi Phala Varga, Shloka No-108, by Dr. Bulusu Sitaram, Volume 1, Chaukhambha Orientalia, Varanasi, First edition 2006, Page No- 385

[76] Acharya Bhavamishra of Bhavaprakasha Nighantu,Amradi Phala Varga, Shloka No-144-146, by Dr. Bulusu Sitaram, Volume 1, Chaukhambha Orientalia, Varanasi, First edition 2006, Page No- 394395 . 